\title{
Is there a Natural Capital? A Critique of the Ecological Economics Approach
}

\section{Fiorenzo Martini}

IRIS (Interdisciplinary Research Institute on Sustainability), University of Torino, Via Giuseppe Verdi, 8, 10124 Torino, Italy

\begin{abstract}
The aim of the paper is to discuss the theoretical foundations of the natural capital concept within the ecological economics framework. The paper does not contest the need to recognize the contribution of ecosystems services to human well-being and social output, nor the issue of the economic evaluation of this contribution. What it intends to question is the reason why nature and natural resources are subsumed into the category of capital; in other words the suitability of the analogy proposed and developed mainly by Costanza and Daly. The paper argues that in this way a monistic distortion (by which everything is considered capital) is introduced and the reciprocal independence among factors of production as sources of value is eliminated. The paper also demonstrates that this view can be traced back to the economics of Irving Fisher, one of the most representative thinkers of the "marginalist revolution" in America.
\end{abstract}

Publication History:

\section{Introduction}

Natural capital is a paradigmatic core concept in ecological economics. The environment as capital is also found in neoclassical environmental economics [1] [2], but only ecological economists "have been at the forefront in developing and popularizing its usage" [3].

The concept plays an important role in both national income accounting and in studies that aim to evaluate the sustainability of development from an inter-temporal perspective [4]; it is also used by those authors that question the state of conservation of critical natural capital, that is to say of the services and functions of ecosystems that cannot be replaced (cf. above all Brand [5], who establishes a significant connection between critical natural capital and ecological resilience).

Even within the recent framework of the TEEB (The Economics of Ecosystems and Biodiversity) international initiative, natural capital is defined as "a useful concept to communicate the value or benefits of nature to mankind" [6].

The concept of a natural capital has been criticised from both the ecological and the social point of view. With respect to the former, it is useful, in particular, to read Harte [7]. The author draws attention to how the highly dynamic characteristics of ecosystems are to a large extent incompatible with the notions of the equilibrium and stability of a stock that must be maintained intact in the course of time. As far as the latter point of view is concerned, it is useful to refer, among others, to Chiesura and de Groot [8], who point out how the importance of natural capital depends on the social groups affected by it.

The following pages aim to propose a criticism based mainly on the categories of economics considered in its historical development. This entails briefly recalling, yet only as far as the topic discussed here is concerned, the essential terms of the highly controversial question of capital in the history of economics.

\section{Capital in the History of Economics}

As historians of economic thought well know, the theory of capital is not a "simple formula" [9] [10].

It is a complex and controversial question that cannot be examined exhaustively according to a clear division between modern economic thought and the classical approach. However, it is not improper to speak of a classical notion of capital (to which it is also possible to ascribe modern thinkers such as Marshall and Böhm- Bawerk) and of a modern notion, the most significant exponents of which are Schumpeter, Hayek, Hicks and Fisher.

We can say that the former sees capital as a totality of fixed assets which has, from the point of view of source, a relationship of causality with the previous production to which it is ideally connected. Furthermore, capital is considered on the same level as the other factors of production.

Such assumptions have been reversed by modern theorists, who emphasise the relationship with the future, superiority as a factor of development and the non-(exclusive)-identification with production equipment. The key thinker of the modern approach is Irving Fisher (see the next paragraph).

\section{Irving Fisher on Capital, Income and Interest}

According to Fisher [11,12], capital is any form of wealth able to produce an income flow. It comprises both durable goods and things for immediate consumption, as well as the personal qualities of people. The value of any element of wealth thus defined depends, according to our author, only on the future, not on the past, that is to say, on the expected income from that capital. In this context, the interest rate is not determined by the amount of capital, but by the interaction between the temporal preferences of income earners and investment opportunities; in other words, interest is an indicator of the preference expressed by the community for a present dollar compared to a future dollar. In this way the traditional perspective is reversed and the production process practically disappears from the analysis.

Fisher's principal objective consists in underlining the distinction between income as a flow of goods and services over time and capital

"Corresponding Author: Dr. Fiorenzo Martini, IRIS (Interdisciplinary Research Institute on Sustainability), University of Torino, Via Giuseppe Verdi, 8, 10124 Torino, Italy, Tel: +39 3316004594; E-mail: fiorenzo.martini@unito.it

Citation: Martini F (2016) Is there a Natural Capital? A Critique of the Ecological Economics Approach. Int J Earth Environ Sci 1: 123. doi: https://doi. org/10.15344/2456-351X/2016/123

Copyright: @ 2016 Martini. This is an open-access article distributed under the terms of the Creative Commons Attribution License, which permits unrestricted use, distribution, and reproduction in any medium, provided the original author and source are credited. 
as a stock of goods at a determined time. In the American economist's perspective, interest is the result of a temporal preference: a preference for a present psychological income (satisfaction) compared to a future income.

In this assertion Fisher would seem to agree fundamentally with the explanation of interest proposed by Böhm-Bawerk [13]. However, in reality there is a great difference between the two theories since, if Böhm-Bawerk believes that it is necessary to explain interest in a manner distinct from the way in which wages and rents are explained, for Fisher interest is not a portion of income that remunerates capital, but rather "a way of examining income flows, whatever type they are"; interest is not a part of, but the whole, income [14]. Unlike in BöhmBawerk, interest is connected not only to the productivity of the stock of a particular category of goods, but also to the inter-temporal preferences of individuals with regard to any type of productive factor (including labour and land).

As is well-known, Fisher's concepts of income and capital are shared by Knight but criticised by Pigou, who considers them more appropriate if one "is interested in comparative amounts of economic wellbeing that a community obtains for a long number of years" [15].

\section{Natural Capital in Ecological Economics}

Costanza and Daly [16] do not agree with the traditional definition of capital as produced means of production, but see a more functional one that is connected to Fisher's elaboration. The notion of capital they adopt is: "A stock that yields a flow of valuable goods or services into the future".

They realise, however, that it is difficult to reconcile this concept with those elements of natural capital, such as most sources of energy, minerals and metals, which, by definition, can only be consumed; they therefore state that the latter are similar to inventories.

As we know from the principles of business administration, inventories consist in finished goods produced and held for sale, in half-finished products and materials and supplies awaiting use in the production process, etc. They are usually calculated in financial statements by their costs of purchase and conversion.

In this way, the authors reintroduce the criterion of what may be produced after having initially excluded it.

Thus, according to these authors, there are two types of natural capital: one of a renewable type, subject to entropic depreciation, which supplies sustainable flows of resources when adequately maintained (sustainable income); the other, non-renewable, similar to inventories, which can only be consumed and, like them, is subject to liquidation.

If on the one hand, as a general definition, Costanza e Daly favour and stress the relationship with the future, on the other they are forced to fall back on the notion of assets produced in order to include particular cases that exist in reality.

Moreover, they associate with this notion of natural capital the concept of human-made capital, further subdivided into two categories: the one (physical) consisting of buildings, machinery, equipment, and the other the stock of education, knowledge and skills stored in human beings (human capital in the strictest sense of the word).
In short, there are assumed to be three types of capital (natural, human, in the strictest sense, and manufactured) that roughly correspond, in these authors' viewpoint, to production factors in classical theory.

In this way, not only land and resources, but all the members of the classical triad, are subsumed into the category of capital. This is totally arbitrary and inadequately argued. The outcome is the capitalisation not only of nature but of society as a whole.

Someone who studies the history of economic thought cannot but raise several objections to Costanza and Daly's operation. First of all, one must ask why they had no recourse to the notion of rent and natural agents, which has an important place in that history. What is the reason why soil, air, water, living organisms are characterized as capital and not as land or natural agents?

Costanza and Daly do not adduce arguments for this choice; they merely say: "In the past, only manufactured stocks were considered as capital because natural capital was superabundant ." Further: "We are now entering an era in which natural capital is becoming the limiting factor." This explanation is clearly tautological.

Secondly, one must question the above-mentioned reductionist attribution of the entire production to one sole agent when the idea of the multi-factor origin of productive activity has accompanied the entire development of economic science. It is true that the triad of productive factors has frequently encountered hostility and been unsuccessful to various degrees, but this has occurred above all for meta-economic and ethical reasons, as Schumpeter, among others, well documented [17]. It is hard to deny, from a scientific point of view, that production in the physical sense requires three different conditions. In particular, capital, and its original characteristics as a distinctive factor of production, along with land and labour, were adduced by Senior in [18].

Paradoxically, mainstream environmental economics reveals a greater awareness of the differences that exist between the depreciation of artificial capital and the deterioration of ecosystems. As one of its most important exponents [19] maintains, the latter is either frequently an irreversible process or requires a long period of time in order to recover; furthermore, ecosystems may suddenly collapse, with hardly any warning.

To this one must also add that the accounting standards that have developed in practice characterise utilisation subject to degradation of natural resources as a component of price rather than a depreciation rate.

We recall them here briefly by referring to the methodological indications of Bolk et al. [20]. These authors bear in mind the distinction between non-renewable components of natural capital (oil, gas, hard coal, lignite, minerals and metals) and renewable components (e.g. forests and commercial timber).

In the former case, it is possible to write:

Rent $=($ Production Volume $)($ International market price - Average unit production cost).

In the latter case, the following formula is applied:

Rent $=(\text { Production }- \text { Natural increment })^{\star}$ Average price ${ }^{\star}$ Rental rate. The latter is the result of estimates by experts and its values are between $30 \%$ and $50 \%$. 
Citation: Martini F (2016) Is there a Natural Capital? A Critique of the Ecological Economics Approach. Int J Earth Environ Sci 1: 123. doi: https://doi. org/10.15344/2456-351X/2016/123

Page 3 of 5

In short, from both the theoretical point of view and from that of empirical developments, there are contradictions and weaknesses in a concept which, according to most ecological economists, is most likely to satisfy the aim to construct a paradigm alternative to the mainstream one.

\section{Conclusion}

Costanza and Daly's definition of natural capital wavers between the concept of the benefit to be drawn from a certain stock in the future and the criterion of what can be produced, introduced in order to include the non-renewable component, which can only be consumed. Moreover, this conceptualisation redefines arbitrarily, without sufficient argumentation, the theory of value based on the triad of productive factors, so that human wealth and well-being come to depend in their entirety on capital alone with its various articulations (manufactured,human and natural).

The consequences of this are a somewhat confused definition and an unwarranted extension. Their concept was highly influenced by the work of Irving Fisher, one of the champions of American marginalism. It is a paradoxical outcome particularly for ecological economics, which is a line of studies whose research programme focuses mainly on overcoming the weaknesses of environmental economics of neoclassical derivation.

These considerations certainly do not mean denying the role of natural resources or the functions and services of ecosystems in the process of the creation of wealth, yet if one wishes to remain anchored to economic categories, such a contribution must be seen within the framework of a broader, clearer scheme that does not deny the differences between the various productive factors and which also foresees recuperating the classical notion of rent.

\section{Competing Interests}

The authors declare that they have no competing interests.

\section{References}

1. Dasgupta $P(2001)$ Human well-being and the natural environment. Oxford University Press.

2. El Serafy (1993) The Environment as Capital. In: Lutz E Towards Improved Accounting for the Environment. World Bank.

3. Burkett $P$ (2006) Marxism and ecological economics. Brill.

4. Arrow K, Dasgupta P, Goulder L, Daily G, Ehrlich P, et al. (2004) Are We Consuming Too Much? Journal of Economic Perspectives 18: 147-172.

5. Brand $F(2009)$ Critical natural revised: ecological resilience and sustainable development. Ecological Economics 58: 605-612.

6. TEEB (2013) The Economics of Ecosystems and Biodiversity: Guidance Manual for TEEB Countries Studies.Version 1.0.

7. Harte MJ (1995) Ecology, sustainability, and environment as capital. Ecological Economics 15:157-164.

8. Chiesura A, de Groot R (2003) Critical natural capital: a socio-cultural perspective. Ecological Economics 44: 219-231.

9. Rosser JB Jr (1991) From catastrophe to chaos: a general theory of economic discontinuities. Kluwer.

10. England R W (2006) Measurement of the Natural Capital Stock: Conceptua Foundations and Preliminary Empirics. In: Lawn P (Ed) Sustainable Development Indicators in Ecological Economics. Edward Elgar.

11. Fisher I (1906) Nature of capital and income. Macmillan.
12. Fisher I (1907) The rate of interest. Macmillan.
13. Böhm- Bawerk E (1891) The Positive Theory of Capital. Macmillan.
14. Landreth H, Colander D C (1994) History of economic thought. Houghton Mifflin.
15. Roll E (1973) A history of economic thought. Faber \& Faber.
16. Costanza R, Daly HE (1992) Natural capital and sustainable development. Conservation Biology 6:37-46.
17. Schumpeter JA (1954) History of economic analysis. Oxford University Press.
18. Senior NW (1965) An Outline of the Science of Political Economy. Kelley
19. Dasgupta P (2007) Economics: A very short introduction, Oxford University Press.
20. Bolt K, Matete M, Clemens M (2002) Manual for Calculating Adjusted Net Savings, Environment Department, World Bank. 